Проф. др Јелена Филиповић

Проф. др Ивана Вучина Симовић

Универзитет у Београду

Филолошки факултет

jelenafbgd@gmail.com

821.163.41.09 Андрић И. 316.342.7(497.6)

ivanavusim@gmail.com https://doi.org/10.18485/ai_andric.2018.ch12

\title{
АНДРИЋЕВА ВИЗИЈА ДРУГОСТИ: БОСАНСКИ ЈЕВРЕЈИ КАО „ЗАМИШЉЕНА ЗАЈЕДНИЦА“
}

Кроз концепт „замишљене заједнице“ Б. Андерсона тумачимо Андрићево романтичарско поимање (првенствено сефардских) Јевреја у Босни и Херцеговини. Наиме, у његовим прозним текстовима уочава се дихотомија „ми“ и „они“, односно, јеврејска заједница се представља као одвојена и битно различита од осталих у комплексном босанском етничко-религијском миљеу. Етнички маркери, у комбинацији са раним национализмом, представљају кључну референтну тачку у Андрићевом тумачењу егзотичности и „другости“ босанских Јевреја. Међутим, у одломцима који се односе на Холокауст, који Андрић доживљава као уједињавајуће трагично искуство Срба и Јевреја, „другост“ се брише и они постају „уништен[и] и искорењен[и] наш[и] сефард[и]“.

Кључне речи: Иво Андрић, сефардски Јевреји у Босни, модерност, национализам, другост, замишљена заједница.

* Рад је настао у оквиру пројекта 178014 Динамика стирукӣура савременої срӣскої језика, који финансира Министарство просвете, науке и технолошког развоја Републике Србије. 


\section{1. Увод: друштвено-историјски \\ и културни контекст}

Вишевековна историја мултиетничких односа на Балкану испуњена је контактима различитих религија, језика, традиција и култура. У њиховом сталном преплитању, настала је густа мрежа идентитета, који су се у различитим епохама и на различите начине стапали и сукобљавали. На раскршћу културних, религијских и политичких сукоба и спајања, Балканско полуострво до средине 19. века осцилира између премодерне, источњачке идеологије Османлијског царства и модерности западне и централне Европе. „Модерност је [...] скуп идеја и аспирација формулисаних од стране Просвећености крајем 18. века и почетком 19. века“ (Жуњић 2009: 107), те представља свеобухватни цивилизацијски конструкт који се рефлектује у политичкој, друштвеној, научној и уметничкој сфери јавног и приватног живота евроцентричног универзума (Хабермас 1981; Бауман и Бригс 2003; Аткинсон 2008; Филиповић 2015). Просветитељство доноси афирмацију грађанске државе, еманципаторску идеју о општој писмености, односно право на образовање за све, прожету романтичарским духом индивидуализације, а потом и идентификације са специфичностима културе и традиције сопственог народа (према: Жуњић 2009), која води ка развоју романтичарске идеје национализма, односно идеализованог вредновања етницитета и националног идентитета који свој одраз налази и у идејама балканских интелектуалаца: „У данашњем времену пробуђене националне свести културних народа Европе Аустро-Угарска представља живи анахронизам“, пише Александар Белић (1915/1991: 9) на почетку Првог светског рата, наводећи да су „[н]екада [...] земљом управљали повлашћени сталежи и тражили оно што је одговарало њиховим интересима, 
мислима и осећањима: а данашњи је владалац државе народ [...]“ (Белић 1915/1991: 94).

Национализам 19. и почетка 20. века, као једна од кључних тековина модерности на Балкану, у складу са специфичним друштвено-историјским и политичким контекстом овог региона, интерпретиран је међу припадницима елита етничко-верских група које су га насељавале као „национално буђење“ и „ослобађање од јарма“ два велика царства (Китромилидес 1989). Такво поимање национализма је уз „европоцентрични (академски) провинцијализам“, довело до стварања „замишљених заједница“, утемељених на „културним артефактима посебног типа“ (Андерсон 1983/1991/2003: хіii). На тај начин, етнички маркери постали су главна обележја како сукоба тако и сарадње, односно на основу њих су поједине групе укључиване или искључиване из „нас“, односно „њих“.

У естетском смислу, рана модерност базира се на супротстављању традиције и садашњости (Хабермас 1981: 4), односно у разоткривању немогућности помирења естетског и друштвеног света (Хабермас 1981: 10). У овом кључу и Иво Андрић пише о Јеврејима у Босни. Од најранијих текстова, попут докторске дисертације, одбрањене на Универзитету у Грацу, 1924. године, преко прозних текстова: романа, приповедака, есеја и пригодних текстова прештампаваним у више наврата у засебним публикацијама и у периодици до после његове смрти, појављују се опсервације о босанским Јеврејима у којима се уочава романтичарска дихотомија „ми“ и „они“, односно у којима се јеврејска заједница посматра као одвојена и битно различита од осталих верско-етничких заједница у Босни, али ипак срасла са њима у суживоту и заједничким недаћама. Управо се на тај аспект поимања јеврејске заједнице у Босни осврћемо користећи термин „замишљена заједница“, потпуно 
свесне чињенице да га не користимо у аутентичном тумачењу које му поставља Бенедикт Андерсон ${ }^{2}$. Не осврћемо се на политичке карактеристике које термин садржи (сувереност), већ на културне импликације (различитост и разграничења у односу на друге етничке заједнице), које сагледане из перспективе „пројекта модерности“ (Хабермас 1981), стварају контекст за „религијски и естетички тонирану екстазу која своју публику налази пре свега у круговима интелектуалаца спремних да поднесу sacrificium intellectus на олтар сопствене потребе за оријентацијом“ (Хабермас 1987: 310).

\section{2. Јевреји из Андрићеве визуре}

\section{1. Андрић и Јевреји: уводне напомене}

Из саме Андрићеве биографије је јасно да је он потекао из средине чији су Јевреји столећима били саставни део ${ }^{3}$. Самим тим, не изненађује често прису-

2 Док ми користимо Андерсонов концепт за анализу Андрићевог поимања међуљудске и међуетничке интеракције у модерно доба, у новијој литератури наилазимо и на другачије виђење „замишљених заједница“" у сефардском контексту. Наиме, уредници зборника Сефараg као замиштена зајеgнииа. Језик, истиорија и релиі̄ија оg раноі̄ моgерної gоба gо ХХI века (Sepharad as Imagined Community: Language, History and Religion from the Early Modern Period to the 21st Century), М. Шаул и Х. И. Уалде (2017) користе овај појам како би указали на мање или више променљиве начине на које су оријентални Сефарди у оквиру својих „транслокалних медитеранских заједница“ сагледавали сопствени идентитет и језик од раног модерног доба до данас.

3 Сефардски Јевреји су дошли на подручје Босне и Херцеговине са простора Османског царства где су пронашли уточиште након прогона с краја 15. века. Оскудни сачувани подаци указују на то да су се они, следећи османско напредовање ка Западу, населили у Сарајеву шездесетих година 16. века. Током првог 
ство и разноврсност јеврејске тематике у његовом опусу. Приличан континуитет у интересовању за јеврејске ликове у Андрићевим делима који се уочава од 1930. године до данас ${ }^{4}$, као и наводи аутора који су их проучавали, сведоче о жељи да се што боље осветле поједини књижевни и културолошки аспекти опуса великог писца, али и да се истовремено ода почаст знаним и незнаним босанским и југословенским Јеврејима који су трагично настрадали током Другог светског рата.

На почетку своје анализе Андрићевих јеврејских ликова и њихове функције у књижевним делима, Кринка Видаковић-Петров указује на важну чињеницу за њихово разумевање: да „није Андрићева намера била да

столећа живели су сконцентрисани у великом хану изграђеном 1581. године, а од половине 17 , а нарочито од почетка 18. века, насељавали су и друге махале у овом граду. У првој половини 19. века јеврејска популација живела је у старој јеврејској четврти и у још шест мешовитих махала, већином муслиманских (Вучина Симовић 2012: 42-43). Сефарди су живели на оријентални начин (који је подразумевао строг патријархални поредак у породици и друштву и живот подређен вери и традицијама) све до аустроугарске окупације (1878), када готово преко ноћи постају део западноевропске цивилизације. Њихово активно учешће у модернизацијским процесима било је додатно подстакнуто доласком ашкенаских Јевреја, који су након окупације почели да се насељавају у већем броју у Босну и Херцеговину из разних крајева аустроугарске империје. Другачији од Јевреја староседелаца по обичајима, менталитету и језику, придошли Ашкенази оснивали су засебне јеврејске општине, школе и верска и лаичка удружења у срединама у којима их је било у довољном броју. Друштвени и језички јаз између две групе почео је да јењава од почетка 20. века, када су их зближиле заједничке ционистичке идеје и активности. Њихово потпуно приближавање догодило се након недаћа које су их задесиле у Другом светском рату (Вучина Симовић 2012: 44-46, 58).

4 Посебно бисмо издвојиле Финци (1930); Струњаш (1967); Пувачић (1986); Константиновић (1991), Ђукић Перишић (2005); Горуп (2006); Инђић (2006); Видаковић-Петров $(2012,2015)$. 
пише посебно о Јеврејима, него о њима као саставном делу мултикултурне и мултиконфесионалне Босне“ (Видаковић-Петров 2012: 192), будући да је „његова [...] основна тема била босанска средина“. У оквиру те теме, „Андрић [je] приступао јеврејству из разних перспектива, комплексно и у контексту општијих тема“" (Видаковић-Петров 2012: 200), дотичући важне проблеме појединаца и заједница:

„Његов приступ манифестује се кроз јеврејске ликове и различиту функцију коју имају у разним делима, тако да се они могу разврстати у шест категорија или типова. Први је психолошки продубљени архетипски лик преузет из старозаветних извора („Победник“). Други тип јавља се превасходно у делима с доминантном историјском потком (Травничка хроника и На Дрини ћуирија): овде су ликови индивидуална отелотворења јеврејске заједнице као интерактивне компоненте босанског мултикултурног простора, те одражавају извесне аспекте колективног менталитета. Трећи тип се јавља у делима у којима се Андрић бави генезом зла, његовим специфичним појавним облицима (антисемитизам) и анализом психологије његових спроводитеља и жртава („Деца“ и „Бифе Титаник“). Четврти тип су јеврејски ликови који се јављају у оквиру теме идентитета (људи „између“), посредовања, преображавања реалности у фикцију, говора и приповедања (Проклетиа авлија, „Речи“, „Писмо из 1920“). Пети тип представљају два женска лика (Рифка из приповетке „Љубав у касаби“ и Лотика из романа На Дрини ћуиррија) којима Андрић у своје сагледавање јеврејских тема уводи родну перспективу. Шести тип представљају секундарни јеврејски ликови у неколико Андрићевих дела (Госӣођица, „Сан и јава под Грабићем“) који превасходно имају функцију изоштравања профила главних ликова (Видаковић-Петров 2012: 200). 
За нашу анализу Андрићеве визије Јевреја као „замишљене заједнице“ и као „других“ послужила су нам дела у којима се појављује други тип из наведене категоризације: то су појединци који представљају оличење своје заједнице у пишчевој историјској визији Босне и Херцеговине. Осим њих, анализирамо и жанровски другачије прозне текстове у којима се он дотиче Јевреја и јеврејства. Наиме, Андрић се на исту заједницу и њене обичаје осврнуо и као врсни познавалац културне историје Босне и Херцеговине у својој докторској дисертацији Развој gуховноі живойа у Босни йоg уйииајем тичрске влаgавине (Грац, 1924), али и као сусед, познаник и пријатељ Јевреја у есеју „На Јеврејском гробљу“ (1954) и пригодним мемоарским текстовима које је написао у знак сећања на Калмија Баруха („Сећање на Калмија Баруха“, 1952; „Помен Калмију Баруху“, 1961) и Исака Самоковлију („Исак Самоковлија“, 1954/1955; „Летњи дан - кратко сећање на младост Исака Самоковлије“, 1955). ${ }^{5}$

\section{2. „Замишљене заједнице“ у Андрићевој историјској визији Босне и Херцеговине}

Концепт „замишљене заједнице“ у Андрићевој визији прошлости Босне и Херцеговине показује се као једна од битних константи његовог богатог опуса. И само Андрићево поимање интеракције различитих босанских верско-етничких група у синхронијској и

5 Ови текстови су прештампани о разним приликама у књижев-

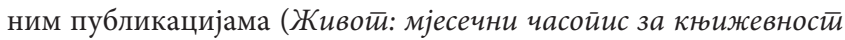
и кулитуру, Савременик, Глас Ояетеюь титерайуре и језика САНУ) и југословенским јеврејским издањима (Јеврејски алманах 1955-1956, 1959-1960, Сйоменица 400 іолина оg gоласка Јевреја у Босну и Хериеіоовин: 1566-1966) још за његова живота, као и након његове смрти. 
дијахронијској перспективи, а међу њима и Јевреја, изражено је кроз „замишљене заједнице“, које се одликује сталном романтизацијом, идеализацијом и апстрактном групном карактеризацијом. Занимљиво је да опредељење за романтичарску визију босанских националних идентитета прожима његове текстове без обзира на њихову жанровску припадност ${ }^{6}$ и упркос чињеници да је у питању миље који му је добро познат и активно присутан и у његовом личном животу.

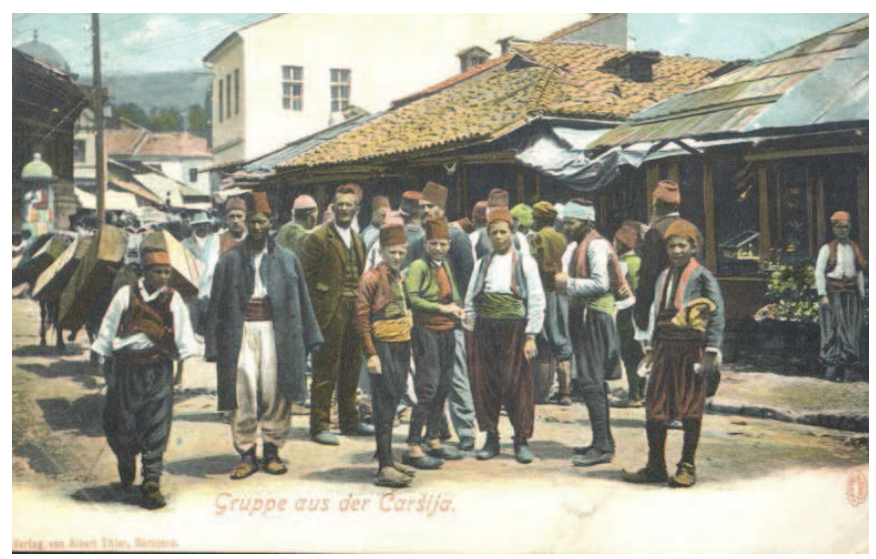

Груйа са чаршије, разіллеgниия

(Народна библиотека Србије, АФ 182)

Мада Андрић позитивно вреднује босанско културно-историјско наслеђе, он управо у непремостивим разликама њених становника проналази узроке вишевековне међусобне мржње, која као нека врста проклетства прати животе њених житеља:

6 У „Предговору“ његове дисертације стоји да је она садржински и концептуално „у вези са другим радовима које [...] [je] припремио у другом облику и другом приликом“ (Андрић 2017: 11). 
Ko u Sarajevu provodi noć budan u krevetu, taj može da čuje glasove sarajevske noći. Teško i sigurno izbija sat na katoličkoj katedrali: dva posle ponoći. Prođe više od jednog minuta (tačno sedamdeset i pet sekundi, brojao sam) i tek tada se javi nešto slabijim ali prodornim zvukom sat sa pravoslavne crkve, i on iskucava svoja dva sata posle ponoći. Malo za njim iskuca promuklim, dalekim glasom sahat-kula kod Begove-džamije, i to iskuca jedanaest sati, avetinjskih turskih sati, po čudnom računanju dalekih, tuđih krajeva sveta! Jevreji nemaju svoga sata koji iskucava, ali bog jedini zna koliko je sada sati kod njih, koliko po sefardskom a koliko po eškenaskom računanju. Tako i noću, dok sve spava, u brojanju pustih sati gluvog doba bdi razlika koja deli ove pospale ljude koji se budni raduju i žaloste, goste i poste prema četiri razna, među sobom zavađena kalendara, i sve svoje želje i molitve šalju jednom nebu na četiri razna crkvena jezika. A ta razlika je, nekad vidljivo i otvoreno, nekad nevidljivo i podmuklo, uvek slična mržnji, često potpuno istovetna sa njom. (Andrić 1991)

Анализирајући у којој мери Андрићево дело одражава визију Југославије као „замишљене заједнице“, А. Вахтел је указао да је овај писац кроз своја књижевна дела, попут других великих националних идеолога, стварао „замишљену југословенску нацију“ на основама „специфичности њеног историјског искуства“ (Вахтел 1995: 83-84). Исти аутор показује да Андрићево бављење историјом кроз разноврсне прозне форме и помоћу различитих „археолошких“ метода није послужило само у замишљању прошлости Босне и Херцеговине, већ и у тумачењу њене садашњости и будућности. Илустрацију за ову појаву Вахтел је пронашао баш у есеју „На Јеврејском гробљу“, у коме Андрић поручује да „историја гробаља има смисла и оправдања уколико баца светлост на пут садашњих или будућих нараштаја“. 


\section{3. Замишљени „ми“ и „они“}

У Андрићевој историјској визији етничко-верски комплексне земље инсистира се на разликама између појединих група, и то често кроз дихотомију „ми“ и „они“, у којој обе стране постају релативно апстрактне и генерализоване појаве са позитивним или негативним предзнаком.

А. Вахтел (1995) истиче да се писац у наративној перспективи представља као „инклузивни наратор у првом лицу множине“ (,inclusive first person plural narrator") који брише границе између приповедања „изнутра“ и „споља“. Он је „инсајдер“ који вешто избегава да се идентификује са било којом од група о којима говори, али је ипак „део земље и народа које описује, укупан збир југословенског историјског процеса, чак и када стоји изван њихових живота“ („,a part of the land and people he describes, the sum total of the Yugoslav historical process, even as he stands outside their lives") (Вахтел 1995: 91).

Наш корпус показује да је у Андрићевом разумевању Јевреја у Босни и Херцеговини диференцирајућа линија између „нас“ и „њих“ јасно видљива, мада праћена позитивним вредновањем разлика, нарочито иберијских корена, језика, вере и традиције сефардских Јевреја.

Кринка Видаковић-Петров (2015) размотрила је пишчево поимање Јевреја као „других“, у оквиру шире типологије другости коју је начинила на основу Травничке хронике. Њени резултати показују да се Јевреји као „други“ битно разликују од осталих „других“ који се „конституишу [...] у стварносном домену и преносе у домен нарације“, а то су „западноевропски други“ који само привремено улази у босански свет с почетка 19. века и „други“ чији се „представници [...] налазе [...] 
'на ивици', истовремено и у два света, али и изван оба“ (Видаковић-Петров 2015: 252-253). У том тумачењу, Јевреји као други су Сефарди, који су етнички, верски, културно и језички другачији од осталих заједница и који су вековима живели затворени у себе и „у паралелном односу, без суштинске комуникације“ са народима из окружења (Видаковић-Петров 2015: 254, 257) 7 .

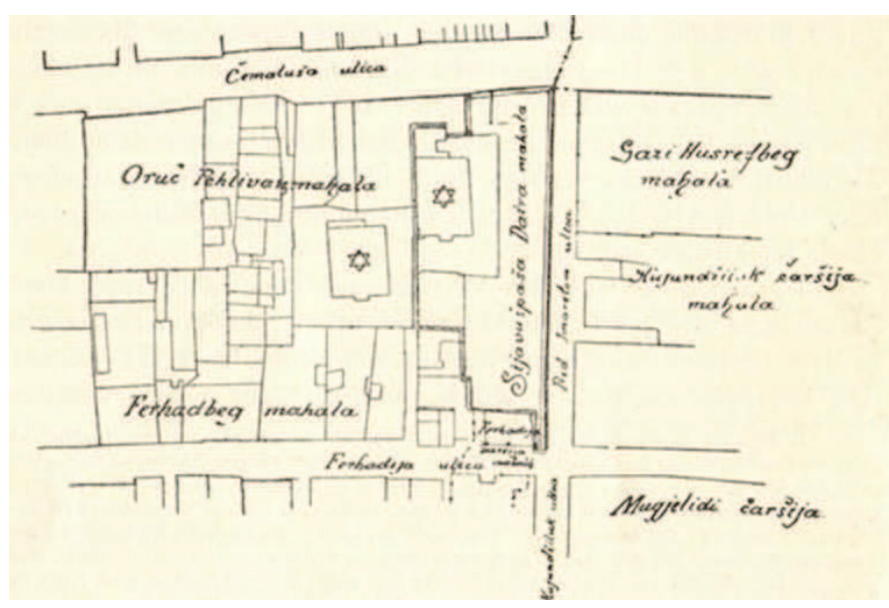

Сијавуи-ӣашина gаира (срп. Велика авлија, јш. Коrtižu) у Сарајеву и оближне махале (Леви 1911: 86)

У есеју „На Јеврејском гробљу“ Сефарди су приказани у оквиру комплексног етничко-религијског миљеа Босне и Херцеговине као „потпуно изоловани

7 Сефардски етнички, верски и језички идентитет се неометано одржавао у оријентално доба захваљујући специфичној аутономији и изолованости њихових заједница, које су као и остале у то доба биле строго патријархалне и дубоко религиозне. Осим тога, Сефарди су одржавали присне друштвене, културне и економске односе са другим сефардским заједницама широм Оријента у оквиру заједничке „културне зоне“, док су имали врло површне контакте са члановима других верско-етничких група у свом непосредном окружењу (Вучина Симовић 2012: 43). 
туђинци, без крвне, верске и језичке везе са осталом рајом“. Међутим, писац то казује уз нескривену емпатију: „Да би се одржали под таквим условима, ови добегли Јевреји морали су да се довијају и повијају још више и теже него што је то морала да чини хришћанска раја“ (Андрић 1956: 257).

Исти извор указује на то да су и јеврејско-шпански језик и хебрејско писмо којим се он писао битни елементи „другости“, али и „фактори изолације“ (Видаковић-Петров 2012):

„Iza svih tih nama nerazumljivih hebrejskih slova, kao iza tanke, ali od svakog zida tvrđe zavese, krije se onaj deo sefardskog života koji su oni održavali kroz duge vekove. Druga takva zavesa, to je njihov španski jezik. Za više od četiri veka, oni su čuvali i pazili taj divni materinski-maćehinski jezik, iako nisu mogli da ga razviju ni da ga sačuvaju da se ne okameni i ne iskvari. Na njemu su pevali svadbene i ljubavne pesme i romanse iz rodne Andaluzije, njime su se služili u intimnom i poslovnom životu.

Ta dva daleka strana pisma i dva tuđa jezika bili su za njih sredstva očuvanja i neophodnog izdvajanja, kao dve šifre u dugoj borbi njihovog života." (Andrić 1956: 259, курзив је наш)

Писац посебно истиче чињеницу да су Ceфарди директни потомци прогнаних Јевреја из Шпаније. Понесен романтичарским заносом, он преноси и распрострањена убеђења настала у модерно доба да су сви сефардски Јевреји потекли из „сунчане Андалузије“ и да су вековима осећали носталгију за изгубљеном „домовином“. У том духу наратор Травничке хронике приповеда „егзотичну“ историју сефардске породице Атијас: 
Koliko se u njihovoj porodici zna, i stari su im, još dok su živeli u Španiji, bili lekari i apotekari. Tu su veštinu Atijasi nastavili i kao prognanici i izbeglice, prvo u Solunu, a zatim u Travniku. [...] U porodici su se čuvale knjige i zabeleške arapskih i španskih čuvenih lekara, koje su Atijasi poneli sa sobom kad su kao izgnanici krenuli iz Andaluzije i kao tajnu dragocenost prenosili sa kolena na koleno. (Andrić 1991: 19)

У есеју „На Јеврејском гробљу“ набројана су сефардска презимена и женска имена како би се што верније пренела „егзотична другост“ сефардске традиције:

Probijam se kroz guste redove grobova, unosim se u obične reči i u poznata i stalno ista prezimena. Abinun, Albahari, Altarac, Atijas, Baruh, Daniti, Danon, Eskenazi, Finci, Gaon, Kabiljo, Kajon, Kalderon, Kamhi, Katan, Konforti, Kunorti, Levi, Maestro, Montilja, Ovadija, Ozmo, Pardo, Pesah, Pinto, Salom. A imena njihovih žena imaju često u sebi nešto od muzike i poezije dalekih sunčanih zemalja: Anula, Gentila, Đoja, Rika, Masalta, Luna, Buena, Palomba, Simha, Oro. (Andrić 1956: 260)

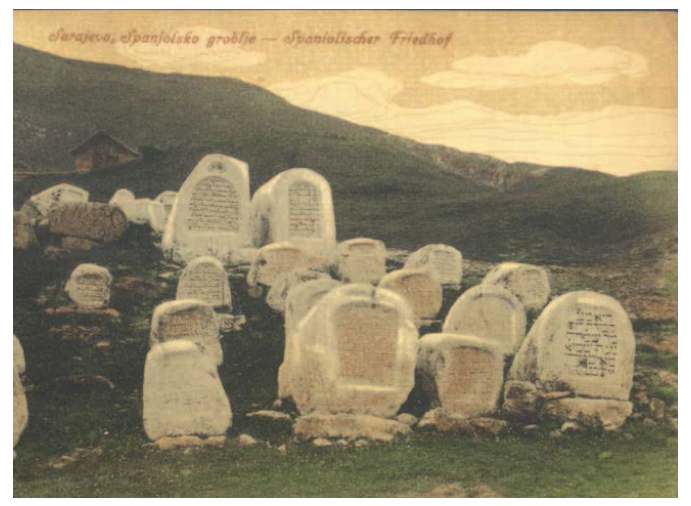

Сйаро сефаряско іроблье у Сарајеву (Народна библиотека Србије Рг 710-IX-001) 
Иако често приказана као одвојена и битно различита од осталих верско-етничких заједница у Босни и Херцеговини, сефардска заједница је за Андрића ипак срасла са њима у суживоту и заједничким недаћама. Из тог разлога нас не чуди што он поклања мању пажњу Ашкеназима, који у већем броју долазе у босанску средину тек од аустроугарске окупације. У следећем одломку писац износи поменуту идеју кроз варијанте дихотомије „ми“ и „они“:

„Njihova istorija, koju će trebati tek napisati [...] pokazaće ne samo sudbinu Sefarda nego i svu raznolikost i složenost našeg društvenog života u prošlosti. Jer, ma koliko da su pretstavljali svet za sebe, oni su u isti mah bili i živ sastavni deo naše opšte zajednice." (Andrić 1956: 258, курзив је наш)

Мада Сефарди представљају за Андрића егзотичан свет, то је свет који он добро познаје још од детињства:

„Iza tih reči i slova nazirem mali i živi sefardski svet iz našeg detinjstva. Trgovce sa visokim fesovima na glavi, pognute nosače, sitne prodavce, zanatlije na ćepencima, njihove stare žene još u sefardskoj orijentalnoj nošnji, njihovu decu, dobro odevenu, bogatašku, i bednu, mršavu, sirotinjsku. Osećam miris njihovih avlija i čujem njihove žive, grlene španske uzvike izmešane sa našim rečima. Svet koga više nema. A da ga nema, to kazuje i ovo groblje živim znacima i vidnim tragovima velike drame jednog naroda.“ (Andrić 1956: 261, курзив је наш)

Финци (1930), указујући на то да су јеврејски ликови код нејеврејских писаца тога доба приказани врло „декоративно“, износи критику да је Андрић писао „Љубав у касаби“ (1923) „без већих претензија на јеврејство“. Међутим, непосредно пре него што је Фин- 
ци изнео ову оцену (мада уз похвалу да представља „најбољу уметничку приповетку о Јеврејима“) Андрић је друговао у Шпанији са босанским Сефардом Калмијем Барухом, захваљујући коме се његово познавање јеврејског миљеа знатно продубило. Барух је био један од ретких Сефарда који су се професионално бавили шпанским језиком и ширењем модерне шпанске књижевности и културе на простору Оријента и конкретно бивше Југославије. Он је био Андрићев водич кроз сефардску и шпанску другост током заједничког боравка у Мадриду и посета значајним шпанским градовима (1928-1929). Андрићеви утисци након њиховог сусрета са шпанским дечаком на улици Сеговије са којим су говорили о прогнаним Јеврејима, исказани у „Сећању на Калмија Баруха“, илуструју у којој мери је писца ганула судбина Сефарда:

„Nas dvojica smo stajali još neko vreme tu u mestu. Negde, na nevidljivoj crkvi, jedno zvono je tuklo jednolično i neumorno kao čekić tupog i nemilosrdnog vremena. Nisam umeo ništa da kažem. Ali sam osećao - i to nije romantičarska figura kojom se služim - kako krila istorije huje iznad naših glava i kako se vekovi čudesno približuju i sučeljavaju. Osećao sam se kao svedok i nemo lice u toj društveno-istorijskoj drami koja je započela u ovoj zemlji pre tri i po veka, koja, kako izgleda, i nema svoga kraja, a jedan tragikomičan čin joj se odigrava sada, na ovom kamenom pločniku, ispod bele table sa modrim slovima.

Doživljaj je bio suviše uzbudljiv, asocijacije koje su iskrsavale i suviše složene i teške, da bismo mogli tu odmah da ga anališemo i rečima izrazimo." (Andrić 1952/1959: 214-215) 


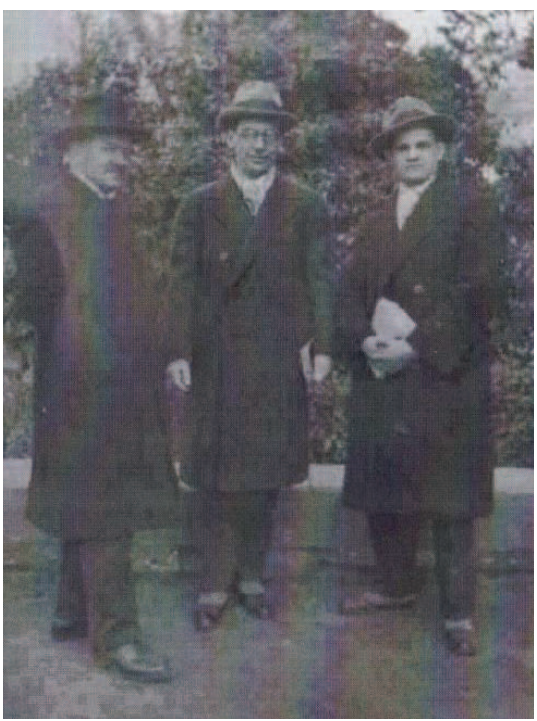

Андрић (у средини) и Барух (први с десна)

у Мадриду у зиму 1928/1929. године (Барух 2005: 165)

У предговору за словеначко издање приповедака Исака Самоковлије, Андрић жели да приближи читаоцима сефардски миље из кога је поникао његов школски друг и колега Сефард и да објасни како су се Сефарди сродили са босанском средином:

Али та заједница се, наравно, није могла отети ни утицају оних са којима је вековима живела заједно. Заједнички живот и потребе свакодневног опхођења доносили су неизбежну инфилтрацију словенских и турских језичких и обичајних елемената у живот наших сефарда. Јер ако су се у синагози служили хебрејским, а у кући шпанским језиком, они су били присиљени да са народом говоре „босански“ а са представницима власти турски. Све је то живот од њих тражио. Придошлице и другачији од нас, они су постали једно са нама. (Андрић 1954/1955: 98) 
О пријатељству између Андрића и Самоковлије сведочи писмо похрањено у Музеју књижевности Босне и Херцеговине у Сарајеву:

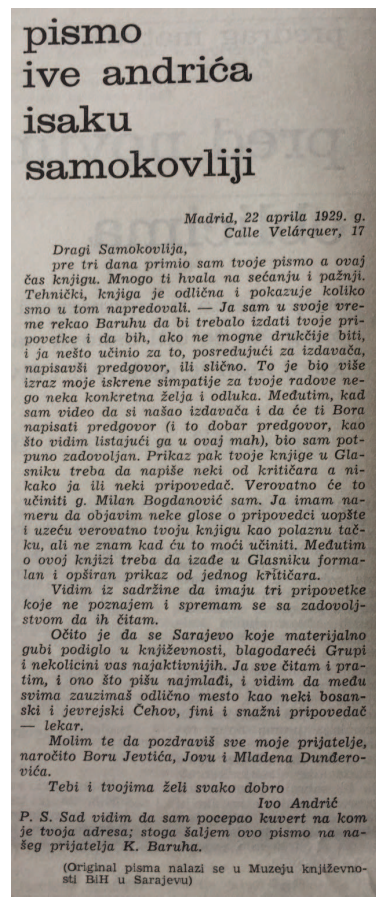

Писмо Иве Андрића уйућено Исаку Самоковлији 1929. іолине из Magpuga (Андрић 1975: 10)

Андрићева осећања кулминирају у одломцима који се односе на Холокауст, у којима се „другост“ брише и они једноставно постају „уништен[и] и искорењен[и] наш[и] сефард[и]“.

To su tragovi posetilaca okupatora ili ustaša, njihove bolesne mržnje i mračne gluposti i njihovih kundaka ili čizama. $[. .$. 
Stojeći, sa dlanom na tom kamenu, kao što će mnogi i mnogi tu stajati, gubim se u živom saučešću, i u mislima o zajedničkoj odbrani koju čovečanstvo, ako hoće da $s$ pravom nosi to ime, mora organizovati protiv svih međunarodnih zločina i tako postaviti sigurnu branu i stvarnu odmazdu protiv svih ubica ljudi i naroda. (Andrić 1956: 261)

Jer, kao što je poznato, tragični, dosledni i neumitni tok istorijskog procesa, čiji sam dah, kako mi se činilo, osetio na uglu mračne ,jevrejske ulice“ u Segoviji, stigao je K. Baruha u njegovim najlepšim godinama [...]. Sa hiljadama i milionima i on je pao kao žrtva zverskog rasizma, propao kao toliki, bez krivice, i bez odbrane. Mi smo izgubili jednog pravog hispanologa. (Govorim to sa opšte tačke gledišta, ostavljajući po strani lično žaljenje i gubitak jednog zaista divnog čoveka i prijatelja ljudi.) (Andrić 1952/1959: 215)

Neka ovaj kratki zapis, u jubilarnom broju našeg Glasa, ostane kao mali pomen na tragičnu sudbinu pravog čoveka i naučnika, našeg druga i zemljaka K. Baruha. (Andrić 1961/1976: 219)

\section{3. Закључна разматрања}

У приказивању Јевреја као „замишљене заједнице“, битно другачије од осталих, Андрић, окренут прошлости, првенствено поклања пажњу аутохтоним Сефардима. Он посебно истиче чињеницу да су ови први директни потомци прогнаних Јевреја из Шпаније који су од половине 16. века водили традиционални и изоловани живот у оквиру комплексног етничко-религијског миљеа Босне и Херцеговине. Стога, сефардски

идентитет и јеврејско-шпански језик и хебрејско писмо 
којим је он писао представљају за њега битне елементе једне егзотичне „другости“.

Ипак, Андрић о тој другости пише са пуно емпатије и уз афирмацију различитости на коју се непрестано позива, у континуираном дијалектичком односу између прихватања и вредновања другости са једне стране и потпуног поистовећивања са перспективом другости, са друге стране. Идентификација и емпатија кулминирају у Андрићевим размишљањима о страдању југословенских Јевреја у Другом светском рату. Истичући да су та горка искуства Јевреји поделили са Србима, писац коначно брише границе између „нас“ и „њих“ и проглашава босанске Јевреје „нашим Јеврејима“. На овај начин „малобројни и потпуно изоловани туђинци, без крвне, верске и језичке везе са осталом рајом“ (Андрић 1955: 257) постају „уништен[и] и искорењен[и] наш[и] сефард[и]“.

Како би се боље разумела ова промена, потребно је да се успостави интердисциплинарна сарадња, као и конструктивни дијалог између истраживача и заинтересованих делатних заједница који прелази преко етничких, верских и језичких граница, и у правом трансдициплинарном смислу повезује „научно утемељена решења проблема из реалног света чији високи степен сложености се огледа у чињеничном колебању, вредносним системима и друштвеним актерима“ („sciencebased solutions to problems in the life-world with a high degree of complexity in terms of factual uncertainties, value loads and societal stakes“) (Визман et al. 2008: 6).

Заправо, кроз комплексно усмерен приступ проучавамо „замишљене заједнице“ (насупрот позитивистичком научном методу насталом из модерности, који све феномене посматра као хомогене и хијерархијски уређене системе), тако што се залажемо за нелинеарно, 
контекстуализовано стварање знања (Филиповић 2015: 29). Са теоријских апстракција прелазимо на анализу међуљудске интеракције, коју сагледавамо као скуп комплексних система (насупрот оним линеарним и устројеним)

[...] који се састоје од делова који се не могу анализирати или разумети независно или у простом један-на-један односу. Чиниоци било ког комплексног система корелирају са другим чиниоцима унутар истог система (као и са члановима других система) на бројне начине и тако производе нове и неочекиване резултате који излазе из оквира просте објективистичке парадигме. Комплексни системи су отворени и осетљиви на повратне информације (Ларсен-Фриман 1997), нелинеарни, пријемчиви, самоорганизовани и прилагодљиви“. (Филиповић 2015: 30)

Овде представљена анализа ослања се на критичку социолингвистику и критичку анализу дискурca, које на комплексан и ангажован начин приступају усменом и писаном дискурсу. У контексту конструктивистичког приступа лингвистичкој анализи сматрамо да се „кроз усмеравање на језичке аспекате друштвене интеракције могу утврдити скривене детерминанте система друштвених односа, као и скривени ефекти које оне могу имати на систем“ (Феркло 2001: 4). Дакле, језик третирамо као један од кључних фактора у конструисању когнитивних културних модела и идеологија које дефинишу и условљавају наше индивидуалне и колективне ставове, веровања, тумачења, осећања и реакције. (Филиповић 2015: 23). Шири циљ овде представљене анализе Андрићеве визије другости и поимања босанских Јевреја као „замишљене заједнице“, јесте да укаже на чињеницу да тумачење писаног 
текста у области лепе књижевности и есејистике такође представља плодно тло за разоткривање когниције која се налази у сржи нашег целокупног разумевања света у коме смо рођени и у коме живимо.

Мишљења смо да ова врста дихотомије у вредновању и тумачењу другог и различитог још увек представља одлику простора на којима живимо. У складу са тим, постулирамо да би свако разматрање променљивих ставова према етницитетима у југоисточној Европи, како у дијахронијској тако и у синхронијској перспективи, требало да се постави као трансдисциплинарни напор који има за циљ да осветли комплексност фактора који леже у основи интеракција како унутар самих група тако и међу групама у вишесложном контексту Балкана, који је одавно престао да буде искључиво географски појам. ${ }^{8}$

\section{Извори и литература}

Андерсон 1983/1991/2003: Anderson, B. Imagined communities. Edinburgh: Verso, 1983/1991/2003. Штампано.

Андрић 1952/1959: Андрић, Иво. „Сећање на Калмија Баруха“. Jevrejski almanah 1959-1960 (1959): 213-215. Штампано. (Прештампано из Андрић, Иво, „Сећање на Калмија Баруха“. Сарајево: Живой: мјесечни часойис за книжевности и кулитуру 3 (дец. 1952): 215-217)

Андрић 1955: Андрић, Иво. „Летњи дан - кратко сећање на младост Исака Самоковлије“. Савременик 2 (фебр. 1955): 254-255. Штампано.

Андрић 1954/1955: Андрић, Иво. „Исак Самоковлија“. Сарајево: Живой: мјесечни часойис за кюижевности и кулūypy IV, 6 (март 1955): 97-99. Штампано. (Прештам-

8 За детаљније информације о трансдисциплинарном, комплексном приступу језичкој анализи, в. Филиповић (2015). 
пано из Andrić, Ivo. „Uvodna beseda“. Samokovlija, Isak. Salomonova črka. 1954. 7-10)

Андрић 1954/1956: Andrić, Ivo. „Na Jevrejskom groblju u Sarajevu“. Jevrejski almanah 1955-1956 (1956): 256-261. Штампано. (Прештампано из Андрић, Иво, „На Јеврејском гробљу у Сарајеву“. Београд: НИН, IV, 156 (01.01.1954): 5)

Андрић 1961/1976: Andrić, Ivo. „Pomen Kalmiju Baruhu“. Umetnik i njegovo delo (eseji, ogledi i članci). tom 2, Sabrana djela Ive Andrića, knj. 13. Sarajevo: Svjetlost, Zagreb: Mladost, Beograd: Prosveta, Ljubljana: Državna založba Slovenije, Skoplje: Misla, 1976. 214-219. Штампано. (Прештампано из Андрић, Иво. „Помен Калмију Баруху“. Глас Оgељьена титиератиуре и језика 251, 6 (1961): 1-4)

Андрић 1975: Andrić, Ivo. „Pismo Ive Andrića Isaku Samokovliji“. Odijek 28, 9 (1-15. maja 1975): 10. Штампано.

Андрић 1991: Andrić, Ivo. Jevrejske priče. Izbor i pogovor Radivoje Konstantinović. Beograd: Narodna knjiga, 1991. Штампано.

Андрић 2017: Андрић, Иво. Развој gуховної животиа у Босни

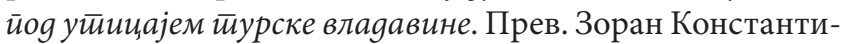
новић. Београд: Етхос, 2017. Штампано.

Аткинсон 2003: Atkinson, D. „Writing for publication/ writing for public execution: On the (personally) vexing notion of (personal) voice“. C. Pearson Casanave \& S. Vandrick (yp.) Writing for scholarly publication. Behind the scenes in language education. Mahwah, NJ: Lawrence Erlbaum Associates, 2008. 189-210. Штампано.

Барух 2005: Baruh, Kalmi. Selected Works on Sephardic and Other Jewish Topics. Krinka Vidaković-Petrov, Alexander Nikolić (yp.). Jerusalem: Moshe David Gaon Center for Ladino Culture, Shefer Publishers, 2005.

Бауман и Бригс 2003: Bauman, Richard \& Charles L. Briggs. Voices of modernity: Language ideologies and the politics of inequality. Cambridge: Cambridge University Press, 2003. Штампано.

Белић 1915/1991: Белић, Александар. Србија и јужнословенско йитиате. Београд: Библиотека града Београда, 
1915/1991. Штампано.

Вахтел 1995: Wachtel, Andrew. „Imagining Yugoslavia: The Historical Archeology of Ivo Andrić“. Wayne S. Vucinich (yp.). Ivo Andrić Revisted: The Bridge Still Stands. Berkeley: University of California, 1995. 82-102. Штампано.

Видаковић-Петров, Кринка. „Јеврејски ликови у делу Иве Андрића“. Научни састианак слависӣа у вукове gане 41-2 (2012): 189-202. Штампано.

Видаковић-Петров, Кринка. „Типологија другог у Травничкој хроници Иве Андрића“. Studia Slavica XIX-2 (2015): 249-258. Штампано.

Визман et al. 2008: Wiesmann, U. et al. „Ehnancing Transdisciplinary Research: A synthesis in Fifteen Points“. G. Hirsch Hadorn et al. (yp.), Handbook of Transdisciplinary Research. Dordecht: Springer, 2008. 433-441. Штампано.

Вучина Симовић 2012: Вучина Симовић, Ивана. „The Sephardim and Ashkenazim in Sarajevo: From social, cultural and linguistic divergence to convergence“. Transversal. Zeitschrift des Centrums fur Jüdische Studien 13, 2 (2012): 4164. Штампано.

Горуп 2006: Gorup, Radmila. „Jewish portraits in the works of Ivo Andrić“. Serbian Studies 20, 1 (2006): 206-208. Штампано.

Д’Андраде 1992: D’Andrade, R. G. „Schemas and motivations“. R. G. D'Andrade \& C. Strauss (yp.), Human motives and cultural models. Cambridge: Cambridge University Press, 1992. 88-119. Штампано.

Д'Андраде 1995: D’Andrade, R. G. „A folk model of the mind“. D. Holland \& N. Quinn (yp.), Cultural models in language and thought. Cambridge: Cambridge University Press, 1995. 112-148. Штампано.

Камерон 2003: Cameron, D. 2003. „Gender and language ideologies“. Janet Holmes \& Miriam Meyerhoff (yp.). The Handbook of Language and Gender. Oxford: Blackwell. 447467. Штампано.

Камерон 2006: Cameron, D. 2006. Ideology and language. Journal of Political Ideologies 11, 2 (2006): 141-152. Штампано.

Ђукић Перишић 2005: Ђукић Перишић, Жанета. Јевреј- 
ски йоритретии у делима Иве Андрића. Toronto: Serbian Literary Company, 2005. Штампано.

Жуњић 2009: Жуњић, Слободан. Моgерности и филозофија: размайрань о gуху времена са размеђа векова. Београд: Плато, 2009. Штампано.

Китромилидес 1989: Kitromilides, Р. М. „'Imagined communities' and the origins of the national question in the Balkans“. European History Quarterly 19 (1989): 149-194. Штампано.

Константиновић 1991: Konstantinović, Radivoje. „Pogovor: Andrićeva jevrejska hronika“. Andrić, Ivo. Jevrejske priče. Izbor i pogovor Radivoje Konstantinović. Beograd: Narodna knjiga, 1991. 128-133. Штампано.

Ларсен-Фриман 1997: Larsen-Freeman, Diane. „Chaos/ Complexity Science and Second Language Acquisition“. Applied linguistics 18, 2 (1997): 141-165. Штампано.

Пувачић, Душан. „Иво Андрић и Јевреји“. Свеске Заяужбине Иве Анgрића 4 (1986): 137-148. Штампано.

Струњаш 1967: Струњаш, Наталија. „Јевреји у југословенској литератури“. Јеврејски алманах 1965-1967 (1967): 115128. Штампано.

Феркло 1989/2001: Fairclough, N. Language and power. $2^{\text {nd }}$ ed.. Longman Publishers. 1989/2001. Штампано.

Филиповић 2009: Filipović Jelena. Moć reči: Ogledi iz kritičke sociolingvistike. Beograd: Zadužbina Andrejević, 2009. Штампано.

Филиповић 2015: Filipović, Jelena. Transdisciplinary approach to language study. The complexity theory perspective. London: Palgrave Macmillan, 2015. Штампано.

Финци 1930: Finci, Eli. „Jevreji u bosanskoj modernoj pripovetci: Nekoliko uzgred zapaženih refleksija“. Jevrejski glas 36-37 (126-127) (23.09.1930): 8. Штампано.

Фриден 2003: Freeden, М. 2003. Ideology. A very short introduction. Oxford: Oxford University Press.

Хабермас 1981: Habermas, J. „Modernity vs. postmodernity“. New German Critique 22, Special Issue on Modernism (Winter 1981): 3-14. Штампано.

Хабермас 1987: Habermas, J. The philosophical discourse of 
modernity. Twelve lectures. Translated by F. Lawrence. Cambridge, UK: Polity Press and Blackwell Publishers Ltd. 1987. Штампано.

Хадсон 2001: Hudson, R. A. Sociolinguistics. Cambridge: Cambridge University press. 2001. Штампано.

Џенкинс 2001: Dženkins, R. Etnicitet u novom ključu. Beograd: XX vek, 2001. (Наслов оригинала: Jenkins, R. Rethinking Ethnicity. London: SAGE Publications, 1997; прев. И. Спасић). Штампано.

Шаул и Уалде 2017: Şaul, Mahir; José Ignacio Hualde. „Sepharad as Imagined Translocal Mediterranean Community“. Şaul, Mahir; José Ignacio Hualde (yp.). Sepharad as Imagined Community: Language, History and Religion from the Early Modern Period to the $21^{\text {st }}$ Century. New York et al: Peter Lang, 2017. 1-25. Штампано.

\section{Jelena Filipović \\ Ivana Vučina Simović}

\section{ANDRIĆ'S VISION OF OTHERNESS: THE JEWS FROM BOSNIA AND HERZEGOVINA AS AN "IMAGINED COMMUNITY"}

\section{Summary}

We apply B. Anderson's concept of "imagined community" in the analysis of Andrićs idealized, romanticized interpretation of the Bosnian (primarily Sephardic) Jews. Establishing a clear dichotomy between "us" and "them", Andrić sees the Jews as completely isolated and separated from all other ethnic and religious groups which have created a thick thread of identities, conflicting and converging in different ways and at different points in time in the region of Bosnia and Herzegovina. Ethnic markers, in correlation with early nationalism, are present as crucial reference points in 
defining conflicts / alliances in Andrićs writings about the Sephardic Jews of Bosnia, as he identifies them as 'other' and 'exotic' (romanticizing their Iberian origins, language, religion and tradition). However, when talking about the Holocaust, understood as a common tragic experience uniting the Serbs and the Jews, Andrić erases "otherness" and writes about "our destroyed and exterminated Sephardim".

Keywords: Ivo Andrić, Sephardic Jews of Bosnia and Herzegovina, modernity, nationalism, otherness, imagined community. 